\title{
The Study of Differences and Influences of Teacher Communication and Discipline Characters of Students
}

\author{
Alfauzan Amin 1" ${ }^{*}$ Alimni2, Dwi Agus Kurniawan³ ${ }^{3}$, Sabila Eka Septi4, Miftahul Zannah \\ Azzahra $^{5}$ \\ 1,2 Faculty of Tarbiyah and Tadris, Universitas Islam Negeri Fatmawati Sukarno , Bengkulu, Indonesia \\ 3,4,5 Faculty of Teaching and Education, Universitas Jambi, Jambi, Indonesia
}

\section{ART ICLE IN F O}

Article history:

Received July 08, 2021

Revised July 11, 2021

Accepted September 20, 2021

Available online November 25, 2021

Kata Kunci:

Pendidikan, Komunikasi Guru,

Karakter Disiplin Siswa

Keywords:

Education, Teacher

Communication, Student Discipline Character

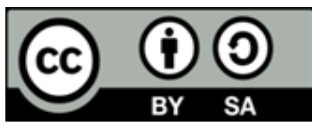

This is an open access article under the CC BY-SA license.

Copyright (C) 2021 by Author. Published by Universitas Pendidikan Ganesha.

\begin{abstract}
A B S T R A K
Pendidikan Agama Islam adalah salah satu mata pelajaran yang berkaitan dengan pembentukan karakter peserta didik di sekolah. Namun, dalam pembentukan karakter disipilin siswa masih kurang diperhatikan dan dikembangkan. Salah satu cara membentuk karakter disipilin siswa yang baik adalah dengan menghubungkan komunikasi guru dan karakter disiplin siswa sehingga siswa dapat memiliki karakter disiplin yang baik. Oleh karena itu, penulis melakukan penelitian terkait komunikasi guru dan karakter disipilin siswa dalam pembelajaran pendidikan agama islam. Tujuan dilakukan penelitian ini adalah untuk mengetahui perbandingan dan pengaruh variabel komunikasi guru dan karakter disipilin siswa sekolah dasar. Jenis penelitian ini menggunakan penelitian mix method dengan desain eksplanatori. Penelitian mix method adalah metode gabungan antara metode penelitian kuantitaif dan metode penelitian kualitatif. Penelitian ini dilakukan dengan menyebarkan angket dan wawancara. Teknik analisis data yang digunakan adalah random sampling. Subjek penelitian dalam penelitian ini adalah 80 siswa di sekolah dasar. Hasil yang diperoleh adalah sekolah dasar 9 Kota Jambi memiliki persentase yang lebih tinggi dibandingkan sekolah dasar 9 Kota Bengkulu sehingga sekolah dasar 9 Kota Jambi memiliki keunggulan dalam komunikasi guru dan karakter disipilin siswa. Kesimpulan dari penelitian ini adalah terdapat perbandingan dan pengaruh komunikasi guru dan karakter disipilin siswa.
\end{abstract}

\begin{abstract}
A B S T R A C T
Islamic education is one of the subjects related to the formation of the character of students in schools. However, in the formation of student discipline character is still less attention and development. One way to form a good student discipline character is to connect teacher communication and student discipline character so that students can have good discipline character. Therefore, the authors conducted research related to teacher communication and student discipline character in learning Islamic religious education. The purpose of this study was to determine the comparison and influence of teacher communication variables and the disciplined character of elementary school students. This type of research uses mixed research methods with an explanatory design. Mixed methods research is a combination of quantitative research methods and qualitative research methods. This research was conducted by distributing questionnaires and interviews. The data analysis technique used is random sampling. The research subjects in this study were 80 students in elementary schools. The results obtained are elementary school 9 Jambi City has a higher percentage than elementary school 9 Bengkulu City so that elementary school 9 Jambi City has advantages in teacher communication and student discipline character. The conclusion of this study is that there is a comparison and influence of teacher communication and student discipline character.
\end{abstract}

\section{INTRODUCTION}

Education is a planned effort to provide guidance in developing self-potential. The main goal for education is to create an intellectual generation and be able to combine the knowledge and skills that are used as the basis for social life (Darmaji et al., 2019; Raharjo et al., 2019; Flores-Tena, 2020). Education has 
a very important position for the progress of a country, with education it can improve the quality of human resources (Johnes et al., 2017; Syahrial et al., 2019; Putri et al., 2020). The 2013 curriculum is the government's implementation to realize the goal of national education, which is to produce a generation that excels in knowledge and skills (Nenotaek et al., 2019; Susilowati, 2017). Education is a very important aspect in the survival of individuals and also one of the efforts of the human learning process to get something better. The 2013 curriculum requires teachers to assess all aspects of development. Attitude is one of the aspects assessed in the 2013 curriculum. Curricular learning in the 2013 Curriculum aims to develop students' attitudes, knowledge, and skills competencies (Cerit, 2013; Lestari, 2018; Wulandari, 2020). Aspects of knowledge and skills are the two main competencies that must be achieved in learning (Af'idayani et al., 2018; Serbin et al., 2020; Swanson et al., 2019). The 2013 curriculum is a curriculum that emphasizes interactive, inspiring, fun, challenging, motivating students to participate actively, as well as providing sufficient space for initiative, creativity, and independence in accordance with the talents, interests, and physical and psychological development of students in accordance with written in the standard process (Maharani, 2015; Sverdlov et al., 2014). Elementary school is an educational institution that organizes educational programs as a basis for preparing students for higher education institutions.

Good learning is involving the entire academic community in elementary schools. Elementary school is a time when children are at the golden age, so it is important to instill noble character values (Broussard \& Garrison, 2004; Hatch \& Clark, 2021; Jampel et al., 2018). Based on the nature of the 2013 Curriculum, the elements that are mostly given to elementary school students are affective aspects and strengthening the learning process and the application of integrated thematics using a scientific approach (Astuti \& Darsinah, 2018; Thoyyibah et al., 2019; Wulandari, 2020). The challenges of education in the world of basic education in the era of the industrial revolution 4.0 require elementary schools to continue to utilize information and communication technology as advanced technology to facilitate the learning process (Bergdahl et al., 2020; Mpungose, 2021; Rachmadtullah et al., 2020; Tondeur et al., 2019). One of the subjects that can be used to grow and increase faith through the provision and fertilization of knowledge and experience of students about the Islamic religion is Islamic religious education.

Islamic Religious Education is one of the subjects related to the formation of the character of students in schools (Arsyad et al., 2020; Madjakusumah et al., 2020; Saputro, 2020). Religious lessons that include fiqh, history of Islamic culture, moral creed and other subjects (Alimin \& Saad, 2019; Saputro, 2020; Yaman et al., 2012). Regarding the subjects of aqidah morals, these subjects are intended so that students acquire basic material related to Islamic morals that are applied in their lives and the formation of characters based on Islamic norms. The teacher carries out activities carried out to encourage, guide and assess students' thinking abilities. so that between teachers and students share information through communication (Fauyan, 2019; Hikmawati, 2020; Latipah et al., 2020). So it can be concluded that Islamic religious education subjects are closely related to teacher communication to create a pleasant atmosphere and can be useful for the formation of student character. Teaching and learning styles are behaviors or actions that teachers and students show during learning (Aulina, 2018; Sucia, 2017; Weng et al., 2019). Teacher competence is related to the concept of the nature and duties of teachers, namely a set of knowledge, skills, and behaviors that must be possessed, internalized, mastered, and actualized by teachers in carrying out their professional duties (Dirgantoro, 2018; Hafid, 2017). Communication is a process of passing symbols from source to receiver (Neveu et al., 2017; Nisa \& Sujarwo, 2020). A process can be built by people who want to get closer to their personalities. The basis is to give the same meaning to the symbol that is conveyed, at least so that people know, people are willing to accept a better direction.

Discipline is one of the means in an effort to form an orderly personality in doing something, discipline can also be in the form of time, in carrying out activities and others. (Barakhsanova et al., 2020; Pratiwi, 2020; Yusoff et al., 2021). Discipline is an attempt to instill values or coercion so that the subject has the ability to obey a rule. Discipline character is an attitude and behavior that arises as a result of training or the habit of obeying rules, laws or orders (Finnane \& Smaal, 2020; Naum, 2018; Su et al., 2019). Elementary school students can be taught to always carry out their duties well by getting used to a disciplined life (Fefer \& Gordon, 2020; Hagenauer et al., 2018; Wang \& Kuo, 2019). So it can be concluded that the character of discipline is very important for elementary school students in shaping personality. The research is in line with previous research about teacher communication (Klemp, 2019; Nisa \& Sujarwo, 2020). However, the previous research only conducted descriptive statistical tests and did not perform several complete tests carried out in this study, namely the assumption test in the form of normality test, linearity test, and homogeneous test. The assumption test is very important to see whether the data being tested is normal or not and to find out that the data is linear and homogeneous. This research is also in line with other previous studies about the character of student discipline (Pratiwi, 2020; Richards et al., 2021). However, previous studies did not compare the character of student discipline with teacher communication. Similar to research on teacher communication, research on student discipline character also does not carry 
out the tests carried out in this study, namely the $\mathrm{T}$ test to determine the comparison of student discipline character variables. So it can be said that the two previous studies did not test some of the tests carried out by this study. The solution that researchers can give is for further testing using variables with more indicators so that more accurate results can be known from research on teacher communication and student discipline character at the elementary school level. The development of this research is by matching many indicators related to variables so that it can be seen that good teacher communication will affect the character of students' discipline in Islamic religious subjects in elementary schools by conducting many tests so that more precise results can be found and can be useful for further research.. The novelty of this research is that this research combines two related variables, namely teacher communication and student discipline character with four indicators where there is rarely research on these two variables at the elementary school level. So the research is an update of the testing of interrelated variables.

The urgency in this study is very important because it is rare to find research that examines the variables of teacher communication and student discipline character. In addition, this study also works to see the importance of teacher communication on the character of students' discipline in Islamic religious education subjects in elementary schools. By looking at the importance of teacher communication with the character of disciplines from questionnaires and interviews. The purpose of this study is to find out how important teacher communication is to the character of Islamic religious disciplines in education subjects in elementary schools and also to find out whether there are differences and teacher communication that affects the character of students' discipline. The purpose of this research can be useful for teachers and students. If the teacher's communication is bad, can it have a big influence on the success of students in good discipline character. Therefore, this research was conducted to find out this purpose.

\section{METHOD}

This research uses mix method research with explanatory design. Mix method research is a combination method between quantitative research methods and qualitative research methods. The explanatory design is carried out in several stages of research, starting with data collection, analyzing data and formulating quantitative analysis results, then proceeding with data collection, analyzing and formulating qualitative data, and ending with interpreting the research results. Instruments in this study used 2 types of instruments, namely questionnaires and interviews. Where the questionnaire used consisted of a discipline character questionnaire and a teacher communication questionnaire as well as interviews conducted with teachers and students. There are 50 valid statement items on this instrument using a Likert scale. The scale consists of 4 points with a very appropriate value is 4 , appropriate is 3 , less appropriate is 2, and not appropriate is 1 . Each statement is representative of each indicator of teacher discipline and communication character. The focus of this research is on 4 dimensions of disciplinary character, namely school rules, learning activities, doing / collecting assignments and using learning facilities. Then the indicators used to measure teacher communication are active communication (twoway), empathy, support, positive feelings and similarities. For the questionnaire grid for this research, it can be seen in Table 1.

Table 1. Grid of Teacher Communication Questionnaire Instruments on Islamic Religious Education Subjects

\begin{tabular}{ccc}
\hline Variable & Indicator & Statement Item Number \\
\hline Teacher & Active communication & $1,2,3,4,5$ \\
communication & Empathy & $6,7,8,9,10,11$ \\
Discipline & School rules & $1,2,3,4,5,6,7,8,9,10$ \\
character & Learning Activities & $11,12,13,14,15$ \\
\hline
\end{tabular}

Due to the character questionnaire of student discipline and teacher communication in Islamic religious education subjects using a Likert scale consisting of 4 categories, there are intervals in each category, and the intervals in each category can be seen in table 2 . The description of the character category of student discipline in Islamic religious education subjects is as follows. The source category of the indicators obtained are indicators created from this research and from the distribution of direct questionnaires conducted in elementary schools 9 Bengkulu City and 9 Jambi City elementary schools. The population of this study was 80 students consisting of 40 elementary school students 9 Bengkulu City and 40 elementary school students 9 Jambi City. The sampling technique is total sampling. The subjects taken were classes VA and VB which consisted of 20 women and 20 men. The reason for taking research subjects from classes VA and VB is because these classes have done a lot of learning so that it can be seen the character of student discipline and teacher communication in the elementary school range. 
Table 2. Categories of Teacher Communication and Student Discipline Character in Islamic Religious Education Subjects

\begin{tabular}{ccccc}
\hline \multirow{3}{*}{ Category } & \multicolumn{4}{c}{ Indicator Interval } \\
\cline { 2 - 5 } & \multicolumn{2}{c}{ Teacher communication } & \multicolumn{2}{c}{ Student discipline character } \\
\cline { 2 - 5 } & $\begin{array}{c}\text { Active } \\
\text { communication }\end{array}$ & Empathy & School rules & Learning Activities \\
\hline Very not good & $5.0-9.0$ & $6.0-11.0$ & $10.0-19.0$ & $5.0-9.0$ \\
Not good & $10.0-13.0$ & $12.0-16.0$ & $20.0-28.0$ & $10.0-13.0$ \\
Good & $14.0-17.0$ & $17.0-21.0$ & $29.0-37.0$ & $14.0-17.0$ \\
Very good & $18.0-21.0$ & $22.0-26.0$ & $38.0-46.0$ & $18.0-21.0$ \\
\hline
\end{tabular}

The data analysis technique used was random sampling because the samples used were elementary school students 9 Bengkulu City and elementary school students 9 Jambi City who studied Islamic religious education subjects according to the variables of teacher communication and student cooperation character. The use of random sampling in this research is to save time, cost and effort, and also allows the results of the research to be more precise and thorough, because all data from smaller research objects will be easier to analyze in detail. The sampling technique is taken because it estimates unbiased parameters and is better if the population is homogeneous (Alsabahi et al., 2021). From these data, descriptive statistical tests and inverential tests were then carried out in the form of testing assumptions and hypotheses. In the assumption test, three tests were carried out, namely normality test, linearity test, and homogeneity test. Normality test serves to determine whether the data is normally distributed. Linearity test serves to determine whether two variables have a linear relationship or not significantly. Homogeneous test serves to find out whether several groups of research data have the same variance or not. Then test the hypothesis in the form of $t$ test and regression test. The t-test serves to determine the comparison of the teacher's communication variables to the student's discipline character. Regression test serves to determine the effect of teacher communication variables on the character of student discipline. These tests were then tested using SPSS 26 to obtain accurate results.

In collecting data, the first thing to do is to select students based on the categories given by the researcher, then give a questionnaire and conduct interviews about the motivation of teachers and the character of student cooperation. Questionnaire is a data collection technique that is done by giving a set of questions or written statements to students. respondents to answer (Sugiyono, 2013). This questionnaire was addressed to students in Elementary School 9 Bengkulu City and Elementary School 9 Jambi City, namely 80 students who became subjects in this study, which aims to determine the effect of teacher and parent communication on the character of student discipline. Then the questionnaire data was processed using the SPSS application. The use of the SPSS application functions to view descriptive statistics in the form of mean, min, max, percentage, and category of students as well as to see the results of several tests such as testing assumptions and testing hypotheses.

\section{RESULT AND DISCUSSION}

\section{Result}

The following describes the results of descriptive statistics on teacher communication variables and students' discipline character. With questions about teacher communication indicators: active communication and empathy. Indicator statements about the character of student discipline: school rules and learning activities. Where the results obtained from the distribution of questionnaires and interviews at Elementary School 9 Bengkulu City and Elementary School 9 Jambi City. The description of teacher communication at SDN 9 Bengkulu City and SDN 9 Jambi City on active communication indicators. The result data is processed using statistics. Descriptive statistics are used to see the mean, median, frequency, percentage by analyzing the results based on the existing categories (Amrhein et al., 2019; Lapinova \& Saichev, 2017). Descriptive statistical test results obtained. The average number of students chose the good category with the percentage for elementary school 9 Bengkulu City 50\% good and elementary school 9 Jambi City 75\% good. So it can be concluded that elementary school 9 Jambi City is superior to elementary school 9 Bengkulu City in active communication indicators. Based on the results of data analysis, it can be seen that the comparison with the good category at elementary school 9 Jambi City is higher than elementary school 9 Bengkulu City so it can be said that Jambi City 9 elementary school is superior to elementary school 9 Bengkulu City in active communication indicators.

The average number of students chose the good category with the percentage for elementary school 9 Bengkulu City $37.5 \%$ good and elementary school 9 Jambi City $50 \%$ good. So it can be concluded that the 
Jambi City 9 Elementary School is superior to the Bengkulu City 9 Primary School in the empathy indicator. The comparison with the good category at elementary school 9 Jambi City is higher than elementary school 9 Bengkulu City so it can be said that Jambi City 9 elementary school is superior to elementary school 9 Bengkulu City in the empathy indicator. The average number of students chose the good category with the percentage for elementary school 9 Bengkulu City 25\% good and elementary school 9 Jambi City 50\% very good. So it can be concluded that the Jambi City 9 Elementary School is superior to the Bengkulu City 9 Primary School in the indicators of school discipline. Based on table 7, the average number of students chose the good category with the percentage for elementary school 9 Bengkulu City 50\% good and elementary school 9 Jambi City 75\% good. So it can be concluded that the Jambi City 9 Elementary School is superior to the Bengkulu City 9 Primary School in the indicators of learning activities.

The comparison with the very good category at elementary school 9 Jambi City is higher than elementary school 9 Bengkulu City so it can be said that Jambi City 9 elementary school is superior to elementary school 9 Bengkulu City in indicators of school discipline. The comparison with the good category in elementary school 9 Jambi City is higher than elementary school 9 Bengkulu City so it can be said that Jambi City 9 elementary school is superior to elementary school 9 Bengkulu City in indicators of learning activities. Normality test is a test that is useful for determining the data that has been collected is normally distributed or not. The data requirements are said to be normally distributed if the value of sig. $>0.05$. Based on the results of data analysis, the data is normally distributed. The normality test was obtained by the Kolmogorov-Smoirnov test, the significance value was $>$ from 0.05 . The linearity test of the variables above has a linear relationship between elementary schools 9 Bengkulu City and elementary schools 9 Jambi cities. It is proven that the result of sig is less than 0.05. Homogeneity test is a test used to determine whether the data used is homogeneous or not. The data requirements are said to be homogeneous if the value of sig. > 0.05. The homogeneity test has a homogeneous pattern in elementary schools in 9 cities in Bengkulu and elementary schools in 9 cities in Jambi. It is proven that the result of sig (2-tailed) is more than 0.05 . In this hypothesis test, the tests carried out are $\mathrm{T}$ test and regression test. The t-test aims to determine whether the independent variable has an effect on the dependent variable while the regression test aims to determine whether or not there is an influence between teacher communication and student discipline character. The description of the results for the $\mathrm{T}$ test of teacher communication and student discipline character at SDN 9 Bengkulu City and SDN 9 Jambi City is shown in the Table 3.

Table 3. Description of the Results for the t-Test of Teacher Communication and Student Discipline characteristics at SDN 9 Bengkulu City and SDN 9 Jambi City

\begin{tabular}{clcc}
\hline School & \multicolumn{1}{c}{ Variable } & N & Sig. (2-tailed) \\
\hline Elementary School 9 & Teacher communication & 40 & 0.048 \\
Bengkulu City & Student discipline character & 40 & 0.047 \\
Elementary School 9 & Teacher communication & 40 & 0.039 \\
Jambi City & Student discipline character & 40 & 0.038 \\
\hline
\end{tabular}

Based on the table above, it can be concluded that there is a comparison between elementary school 9 Bengkulu City and elementary school 9 Jambi City. Proven from the results of sig. (2-tailed) is less than 0.05. Based on the results of data analysis, there is a relationship between elementary school 9 Bengkulu City and elementary school 9 Jambi City. Proven from the results of sig. smaller than 0.05 . The results of interviews with students at SDN 9 Bengkulu City and SDN 9 Jambi City, the first question is whether the teacher communicates with your children in a pleasant way? And the answers from students from these schools on average answered that their teachers had communicated pleasantly and there were also those who thought that their teachers had not communicated pleasantly. Then the second question is whether teacher communication affects the character of your child's discipline? And the students' answers from the school argued that teacher communication greatly influenced the character of students' discipline. Then the third question is if there is a problem with your child's discipline, does the teacher give advice on your child's problem? And the answers of students from these schools on average answered that their teachers helped solve problems faced by their students. Then the last question is whether the teacher always demands your child to be disciplined in the learning process? And the students' answer from these schools is that their teachers always demand discipline in the learning process.

\section{Discussion}

Based on the results of interviews with students, it can be seen that most of the teachers have made pleasant communication to their students. With good and pleasant teacher communication to students, it must have an effect on the character of the students' discipline (Bdiwi et al., 2019; Gil-Flores et al., 2017; 
König et al., 2020). Every disciplinary problem experienced by students, most of the teachers have tried to help find solutions or solve the problems of their students' disciplinary problems and every teacher always requires students to be disciplined so that the learning process goes well and for the good of students going forward (Fathema \& Akanda, 2020; Johansson et al., 2020; Wegmann \& Smith, 2019). This research is in line with previous research about teacher communication (Klemp, 2019; Nisa \& Sujarwo, 2020). However, previous studies did not perform several tests carried out in this study, one of which was the regression test and the indicators used in the test were limited. Regression test serves to determine the effect of the character of cooperation with student responses. This research is also in line with previous research about the character of student discipline, but in this study it did not compare the character of student discipline with teacher communication, nor did this study carry out a complete test as was done in this study (Pratiwi, 2020; Richards et al., 2021). So it can be said that previous research is not as clear and detailed as this research.

The generalization and updating of this research is to find out the comparison and influence of teacher communication and student discipline character. Where there is no research that examines teacher communication and student discipline character in two elementary schools with different cities. So that with this research, it can be known in more detail and accurately based on the tests that have been carried out by this research. The character of student discipline is very important to students in existing learning in order to form a good personality (Naum, 2018; Su et al., 2019; Suyanto, 2018). In carrying out this research, it can be seen that teacher communication greatly influences the character of students' discipline in Islamic religious education subjects in elementary schools (Bdiwi et al., 2019; König et al., 2020). The implication of this research is that teacher communication is very important for the character of student discipline and can be implemented on student learning outcomes if teacher communication is good it will affect the character of student discipline so that students do not have difficulty learning and student learning outcomes will increase. In this study it was found that teacher communication was very good. This is very influential in growing students' disciplined character in learning Islamic religious education (Cain, 2020; Fefer \& Gordon, 2020; Richards et al., 2021). Thus, teacher communication can be implemented with a very good student discipline character in elementary school students. The limitation of this study is that it only compares the variables between teacher communication and student discipline characters. but has not been tested with other variables such as parental communication. Where teacher communication is very important to know the comparison and influence of student discipline character on learning success. So that variables such as parental communication to be tested in further research. Researchers suggest to conduct further research to compare the variables of teacher communication and student discipline character with other variables such as teacher communication and researchers suggest to conduct research at the elementary school level.

\section{CONCLUSION}

There is a comparison between teacher communication and student discipline character in elementary school 9 Bengkulu City and elementary school 9 Jambi City as well as in Islamic religious education subjects and there is an influence between teacher communication and student discipline character in school elementary school 9 Bengkulu City and elementary school 9 Jambi City as well as in Islamic religious education subjects.

\section{REFERENCES}

Af'idayani, N., Setiadi, I., \& Fahmi. (2018). The Effect of Inquiry Model on Science Process Skills and Learning Outcomes. European Journal of Education Studies, 4(12), 177-182. https://doi.org/10.5281/zenodo.1344846.

Alimin, F. G., \& Saad, M. S. M. (2019). The Effectiveness of Google Classroom as an Instructional Media: A Case of State Islamic Institute of Kendari, Indonesia. Journal of Humanities and Social Sciences, $7(2)$. https://doi.org/10/18510/hssr.2019.7227.

Alsabahi, M. A., Maisurah, K., Bahador, K., \& Saat, R. M. (2021). Cogent Business \& Management The influence of personal characteristics and workplace learning on information technology competency among external auditors: The role of organisational culture as a moderator The influence of personal characteristics and wo. Cogent Business \& Management, 8(1). https: //doi.org/10.1080/23311975.2021.1899625.

Amrhein, V., Trafimow, D., \& Greenland, S. (2019). Inferential Statistics as Descriptive Statistics: There Is No Replication Crisis if We Don't Expect Replication. American Statistician, 73(sup1), 262-270. https://doi.org/10.1080/00031305.2018.1543137. 
Arsyad, A., Sulfemi, W. B., \& Fajartriani, T. (2020). Penguatan Motivasi Shalat Dan Karakter Peserta Didik Melalui Pendekatan Pembelajaran Kontekstual Pada Mata Pelajaran Pendidikan Agama Islam. POTENSIA: Jurnal Kependidikan Islam, 6(2), 185. https://doi.org/10.24014/potensia.v6i2.9662.

Astuti, S. I., \& Darsinah, D. (2018). Penilaian Autentik Berbasis Kurikulum 2013 di SD Negeri Mangkubumen Kidul No. 16 Surakarta. Manajemen Pendidikan, 13(2), 165-174. https://doi.org/10.23917/jmp.v13i2.7484.

Aulina, C. N. (2018). Penerapan Metode Whole Brain Teaching dalam Meningkatkan Motivasi Belajar Anak Usia Dini. Jurnal Obsesi : Jurnal Pendidikan Anak Usia Dini, 2(1), 1. https://doi.org/10.31004/obsesi.v2i1.1.

Barakhsanova, E. A., Prokopyev, M. S., Olesova, S. G., Olesov, N. P., Lukina, T. N., Sorochinskiy, M. A., \& Tatarinov, F. F. (2020). Transdisciplinary Approach To the Learning Process Organization in the ELearning Information Environment of a College. International Transaction Journal of Engineering Management I\& Applied Sciences I\& Technologies, 11(3), 1-12. https://doi.org/10.14456/ITJEMAST.2020.53.

Bdiwi, R., de Runz, C., Faiz, S., \& Cherif, A. A. (2019). Smart learning environment: Teacher's role in assessing classroom attention. Research in Learning Technology, 27, 1-14. https://doi.org/10.25304/rlt.v27.2072.

Bergdahl, N., Nouri, J., \& Fors, U. (2020). Disengagement, engagement and digital skills in technologyenhanced learning. Education and Information Technologies, 25(2), 957-983. https://doi.org/10.1007/s10639-019-09998-w.

Broussard, S. C., \& Garrison, M. E. B. (2004). The relationship between classroom motivation and academic achievement in elementary-school-aged children. Family and Consumer Sciences Research Journal, 33(2), 106-120. https://doi.org/10.1177/1077727X04269573.

Cain, J. P. (2020). A qualitative study on the effect of podcasting strategies (studycasts) to support 7th grade student motivation and learning outcomes. Middle School Journal, 51(3), 19-25. https://doi.org/10.1080/00940771.2020.1735867.

Cerit, Y. (2013). Relationship between Teachers' Self-Efficacy Beliefs and Their Willingness to Implement Curriculum Reform. International Journal of Educational Reform, 22(3), 252-270. https://doi.org/10.1177/105678791302200304.

Darmaji, D., Kurniawan, D. A., \& Irdianti, I. (2019). Physics education students' science process skills. International Journal of Evaluation and Research in Education, 8(2), 293-298. https: //doi.org/10.11591/ijere.v8i2.28646.

Dirgantoro, K. P. S. (2018). Kompetensi Guru Matematika Dalam Mengembangkan Kompetensi Matematis Siswa. Scholaria: Jurnal Pendidikan Dan Kebudayaan, 8(2), 157-166. https: //doi.org/10.24246/j.js.2018.v8.i2.p157-166.

Fathema, N., \& Akanda, M. H. (2020). Effects of instructors' academic disciplines and prior experience with learning management systems: A study about the use of Canvas. Australasian Journal of Educational Technology. https://doi.org/10.14742/AJET.5660.

Fauyan, M. (2019). Developing Interactive Multimedia Through Ispring on Indonesian Language Learning with The Insights of Islamic Values in Madrasah Ibtidaiyah. Al Ibtida: Jurnal Pendidikan Guru MI, 6(2), 177. https://doi.org/10.24235/al.ibtida.snj.v6i2.4173.

Fefer, S. A., \& Gordon, K. (2020). Exploring perceptions of school climate among secondary students with varying discipline infractions. International Journal of School and Educational Psychology, 8(3), 174-183. https://doi.org/10.1080/21683603.2018.1541033.

Finnane, M., \& Smaal, Y. (2020). Character, Discipline, Law: Courts Martial in World War I. Australian Historical Studies, 51(3), 324-340. https://doi.org/10.1080/1031461X.2020.1741657.

FLORES-TENA, M. J. (2020). The Educational Inclusion in the Deficit of Attention of Elementary Students. International Journal of Educational Research Review, 265-273. https://doi.org/10.24331/ijere.747244.

Gil-Flores, J., Rodríguez-Santero, J., \& Torres-Gordillo, J. J. (2017). Factors that explain the use of ICT in secondary-education classrooms: The role of teacher characteristics and school infrastructure. Computers in Human Behavior, 68, 441-449. https://doi.org/10.1016/j.chb.2016.11.057.

Hafid, M. (2017). Pengaruh Motivasi dan Kompetensi Guru Terhadap Kinerja Guru Sekolah dan Madrasah di Lingkungan Pondok Pesantren Salafiyah Syafi'iyah Sukorejo. Jurnal Pendidikan Islam Indonesia, 1(2), 293-314. https://doi.org/10.35316/jpii.v1i2.55.

Hagenauer, G., Gläser-Zikuda, M., \& Moschner, B. (2018). University students' emotions, life-satisfaction and study commitment: a self-determination theoretical perspective. Journal of Further and Higher Education, 42(6), 808-826. https://doi.org/10.1080/0309877X.2017.1323189.

Hatch, L., \& Clark, S. K. (2021). A study of the instructional decisions and lesson planning strategies of highly 
effective rural elementary school teachers. Teaching and Teacher Education, 108. https://doi.org/10.1016/j.tate.2021.103505.

Hikmawati, N. (2020). Model Pembelajaran Kurikulum 2013 Dalam Materi Ipa Kelas 6 Mi Miftahun Najah Desa Tenonan Kecamatan Manding. Jurnal Kariman, 8(1), 89-104. https://doi.org/10.52185/kariman.v8i1.129.

Jampel, I. N., Fahrurrozi, Artawan, G., Widiana, I. W., Parmiti, D. P., \& Hellman, J. (2018). Studying natural science in elementary school using nos-oriented cooperative learning model with the NHT type. Jurnal Pendidikan IPA Indonesia, 7(2), 138-146. https://doi.org/10.15294/jpii.v7i2.9863.

Johansson, L. G., Grønvad, J. F., \& Budtz Pedersen, D. (2020). A matter of style: Research production and communication across humanities disciplines in Denmark in the early-twenty-first century. Poetics, 83(May), 101473. https://doi.org/10.1016/j.poetic.2020.101473.

Johnes, J., Portela, M., \& Thanassoulis, E. (2017). Efficiency in education. Journal of the Operational Research Society. https://doi.org/10.1057/s41274-016-0109-z.

Klemp, T. (2019). Early mathematics-teacher communication supporting the pupil's agency. International Journal of Primary, Elementary and Early Years Education, 1-14. https://doi.org/10.1080/03004279.2019.1663893.

König, J., Jäger-Biela, D. J., \& Glutsch, N. (2020). Adapting to online teaching during COVID-19 school closure: teacher education and teacher competence effects among early career teachers in Germany. European Journal of Teacher Education, 43(4), 608-622. https://doi.org/10.1080/02619768.2020.1809650.

Lapinova, S., \& Saichev, A. (2017). Comparative statistics of Garman-Klass, Parkinson, Roger-Satchell and

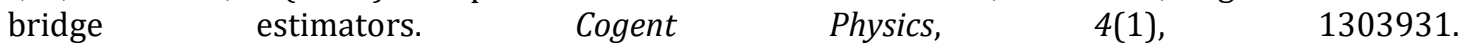
https://doi.org/10.1080/23311940.2017.1303931.

Latipah, E., Kistoro, H. C. A., \& Khairunnisa, I. (2020). Scientific Attitudes in Islamic Education Learning: Relationship and the Role of Self-Efficacy and Social Support. Edukasia: Jurnal Penelitian Pendidikan Islam. https://doi.org/10.21043/edukasia.v15i1.7364.

Lestari, N. D. (2018). Analisis Penerapan Kurikulum 2013 Dalam Meningkatkan Kualitas Pembelajaran Ekonomi Di Sma Negeri Se-Kota Palembang. Jurnal Neraca: Jurnal Pendidikan Dan Ilmu Ekonomi Akuntansi, 2(1), 68-79. https://doi.org/10.31851/neraca.v2i1.2190.

Madjakusumah, D. G., Saripudin, U., \& Suryani, S. (2020). Rekayasa dan Penguatan Lembaga Menghadapi Persaingan Global Berbasis Wirausaha dan Etika Islam. Journal of Islamic Economic and Business, 3(1). https://doi.org/10.21154/elbarka.v3i1.2014.

Maharani, Y. S. (2015). Efektivitas Multimedia Pembelajaran Interaktif Berbasis Kurikulum 2013. Indonesian Journal of Curriculum and Educational Technology Studies, 3(1), 31-40. https://doi.org/10.15294/ijcets.v3i1.8683.

Mpungose, C. B. (2021). Lecturers' reflections on use of Zoom video conferencing technology for e-learning at a South African university in the context of coronavirus. African Identities. https://doi.org/10.1080/14725843.2021.1902268.

Naum, M. (2018). Cultural 'improvement', discipline and mining in early modern Sápmi. Post-Medieval Archaeology, 52(1), 102-116. https://doi.org/10.1080/00794236.2018.1461328.

Nenotaek, B., Sujadi, I., \& Subanti, S. (2019). The Difficulties in Implementing Scientific Approach for Mathematics Learning. International Journal of Educational Research Review. https://doi.org/10.24331/ijere.628448.

Neveu, M. J., Jackson, D., Greene, D., White, M., Jones, W., Hight, C., \& Clouse, C. (2017). The Design of Environmetal Design. Journal of Architectural Education, 71(2), 135-286. https://doi.org/10.1080/10464883.2017.1409001.

Nisa, K., \& Sujarwo, S. (2020). Efektivitas Komunikasi Guru terhadap Motivasi Belajar Anak Usia Dini. Jurnal Obsesi : Jurnal Pendidikan Anak Usia Dini, 5(1), 229. https://doi.org/10.31004/obsesi.v5i1.534.

Pratiwi, S. I. (2020). Pengaruh Ekstrakurikuler Pramuka Terhadap Karakter Disiplin Siswa SD. Edukatif: Jurnal Ilmu Pendidikan, 2(1), 62-70. https://doi.org/10.31004/edukatif.v2i1.90.

Putri, N. P. J. E., Artini, L. P., \& Wahyuni, L. G. E. (2020). EFL Teachers' Perception and Strategies for Integrating Character Education into the Lesson. Jurnal Pendidikan Dan Pengajaran. https://doi.org/10.23887/jpp.v53i1.19172.

Rachmadtullah, R., Yustitia, V., Setiawan, B., Fanny, A. M., Pramulia, P., Susiloningsih, W., \& Tur, C. (2020). The Challenge Of Elementary School Teachers To Encounter Superior Generation In The 4. 0 Industrial Revolution : Study Literature. 9(04), 2018-2021.

Raharjo, Y. K., . S., \& . W. (2019). Need Analysis of Learning Model of History Integrated with Leadership Values of Mangkunegara I through Reflective Pedagogy Paradigm. International Journal of Educational Research Review, 4(4), 617-623. https://doi.org/10.24331/ijere.628436. 
Richards, T. N., Holland, K., Kafonek, K., \& Navarro, J. (2021). Sex-Based Harassment in the United States' K12 Schools: Rates and Predictors of Allegations, Student Reporting, and Student Discipline. Journal of School Violence, 00(00), 1-15. https: //doi.org/10.1080/15388220.2021.1920423.

Saputro, F. E. (2020). The Role Of Islamic Religious Education Teachers In Actualizing Tolerance Attitudes To Students. AL-ISHLAH: Jurnal Pendidikan, 12(2), 336-347. https://doi.org/10.35445/alishlah.v12i2.214.

Serbin, K. S., Robayo, B. J. S., Truman, J. V., Watson, K. L., \& Wawro, M. (2020). Characterizing quantum physics students' conceptual and procedural knowledge of the characteristic equation. The Journal of Mathematical Behavior, 58. https://doi.org/10.1016/j.jmathb.2020.100777.

Su, D., Toure, D., Do, K., \& Ramos, A. K. (2019). Assessing Racial and Ethnic Differences in Attitudes towards the Use of Physical Discipline in Parenting: A Mixed-Methods Approach. Journal of Social Service Research, 45(4), 455-465. https: / /doi.org/10.1080/01488376.2018.1480570.

Sucia, V. (2017). Pengaruh Gaya Komunikasi Guru Terhadap Motivasi Belajar Siswa. Komuniti : Jurnal $\begin{array}{lllll}\text { Komunikasi Dan } & \text { Teknologi }\end{array}$ https://doi.org/10.23917/komuniti.v8i5.2942.

Sugiyono. (2013). Metode Penelitian Kuantitatif Kualitatif dan R\&D. Cetakan ke-18. CV Alfabeta.

Susilowati, S. (2017). Pengembangan Bahan Ajar IPA Terintegrasi Nilai Islam untuk Meningkatkan Sikap dan Prestasi Belajar IPA Siswa. Jurnal Inovasi Pendidikan IPA, 3(1), 78-88. https://doi.org/10.21831/jipi.v3i1.13677.

Suyanto, S. (2018). Competence and discipline on work motivation and the implication on working performance. European Research Studies Journal, 21(1), 570-587. https://doi.org/10.35808/ersj/971.

Sverdlov, A., Aram, D., \& Levin, I. (2014). Kindergarten teachers' literacy beliefs and self-reported practices: On the heels of a new national literacy curriculum. Teaching and Teacher Education, 39. https://doi.org/10.1016/j.tate.2013.12.004.

Swanson, E., McCulley, L. V., Osman, D. J., Scammacca Lewis, N., \& Solis, M. (2019). The effect of team-based learning on content knowledge: A meta-analysis. Active Learning in Higher Education, 20(1), 39-50. https://doi.org/10.1177/1469787417731201.

Syahrial, Asrial, Kurniawan, D. A., \& Piyana, S. O. (2019). E-Modul Etnokontruktivisme: Implementasi Pada Kelas V Sekolah Dasar Ditinjau Dari Persepsi, Minat Dan Motivasi. JTP - Jurnal Teknologi Pendidikan, 21(2), 165-177. https://doi.org/10.21009/jtp.v21i2.11030.

Thoyyibah, N., Hartono, R., \& Bharati, D. A. L. (2019). The Implementation of Character Education in the English Teaching Learning Using 2013 Curriculum. English Education Journal, 9(2), 254-266. https://doi.org/10.15294/eej.v9i2.30058.

Tondeur, J., Scherer, R., Baran, E., Siddiq, F., Valtonen, T., \& Sointu, E. (2019). Teacher educators as gatekeepers: Preparing the next generation of teachers for technology integration in education. British Journal of Educational Technology, 50(3), 1189-1209. https://doi.org/10.1111/bjet.12748.

Wang, W. L., \& Kuo, C. Y. (2019). Relationships Among Teachers' Positive Discipline, Students' Well-being and Teachers' Effective Teaching: A Study of Special Education Teachers and Adolescent Students With Learning Disabilities in Taiwan. International Journal of Disability, Development and Education, 66(1), 82-98. https://doi.org/10.1080/1034912X.2018.1441978.

Wegmann, K. M., \& Smith, B. (2019). Examining racial/ethnic disparities in school discipline in the context of student-reported behavior infractions. Children and Youth Services Review, 103. https://doi.org/10.1016/j.childyouth.2019.05.027.

Weng, F., Ho, H. J., Yang, R. J., \& Weng, C. H. (2019). The influence of learning style on learning attitude with multimedia teaching materials. Eurasia Journal of Mathematics, Science and Technology Education, 15(1), 1-9. https://doi.org/10.29333/ejmste/100389.

Wulandari, I. G. A. A. (2020). Implementation of the 2013 Curriculum Based on a Scientific Approach (Case Study at SD Cluster II Kintamani). International Journal of Elementary Education, 4(3), 422-430. https://doi.org/10.23887/ijee.v4i3.28172.

Yaman, R., Alias, Z., \& Ishak, N. M. (2012). Beauty Treatment and Spa Design from Islamic Perspective. Procedia - Social and Behavioral Sciences, 50. https://doi.org/10.1016/j.sbspro.2012.08.053.

Yusoff, Hisyam, M., Azra, A., \& Fatimah. (2021). Metacognitives And Morals: The Qur' an As A Guide Research Article Metacognitives And Morals : The Qur' an As A Guide. Turkish Journal of Computer and Mathematics Education, 12(4), 659-664. https://doi.org/10.17762/turcomat.v12i4.550. 